\title{
A LITERATURA E AS ARTES DEPOIS DA VIRADA ICÔNICA
}

O exame das relações entre obras literárias e obras de artes plásticas sempre foi uma das abordagens centrais do que conhecemos como Literatura Comparada - aliás, mesmo muito antes que esta se constituísse como ramo relativamente autônomo dos estudos literários: veja-se o tema clássico do paragone ou da rivalidade entre as artes. Um dos momentos de renovação desta abordagem foi aquele da assim chamada "virada icônica" ou "virada imagética”. Recordando: no início dos anos 1990, W. J. T. Mitchell falou em pictorial turn, Ferdinand Fellmann em imagic turn e Gottfried Boehm em ikonische Wendung, designações que apontam, todas elas, para uma efetiva ou suposta superação do paradigma linguístico que havia dominado o pensamento ocidental das décadas anteriores. Com essa virada, vem para a boca da cena crítica e teórica não apenas a hegemonia da imagem nessa época, mas também, sobretudo, o caráter problemático da imagem: sua configuração conflitiva, sintomática, anacrônica (ou, mais exatamente, heterocrônica), a um só tempo lacunar e excessiva. A própria história, nesse movimento, passa a ser pensada a partir das imagens - por exemplo, através da recuperação da noção de imagem dialética, de Walter Benjamin, por filósofos como Giorgio Agamben e Georges Didi-Huberman. É nesse quadro que Didi-Huberman dirá que "sempre, diante da imagem, nós estamos diante do tempo". Levando esse raciocínio adiante, podemos dizer que sempre, diante das instituições e das práticas que envolvem as imagens, estamos diante da história como proliferação de instâncias dialéticas, que devem ser pensadas em toda sua complexidade.

Essa virada - que foi icônica ou imagética, mas também, em alguma medida, museal e curatorial - teve consequências decisivas para os estudos literários e, mais amplamente, para a vida social da literatura. Isso desde os 
níveis mais básicos: sem ela, não teríamos hoje instituições como o Museu da Língua Portuguesa ou ainda a multiplicação de museus dedicados a escritores ou mesmo a movimentos literários; tampouco a cena literária teria sido dominada pela prática da curadoria, antes reservada às artes visuais, em coleções, festas, festivais, prêmios etc. - numa disputa aberta ou implícita com a já antiga figura do editor. Tampouco, num plano um pouco mais sofisticado, estaríamos diante de noções como aquela de "literatura num campo expandido" - segundo uma denominação tomada de empréstimo às considerações da crítica de arte Rosalind E. Krauss sobre escultura.

A proposta do dossiê deste número da revista Remate de Males é reunir artigos que tratem de questões derivadas desse novo modo de encarar as relações entre as artes da palavra e as artes ditas visuais ou plásticas, como a relevância da ideia de museu para se pensar a literatura moderna e contemporânea, a presença de obras literárias em exposições (assim como a exposição como procedimento literário), a dimensão poético-escritural de boa parte da arte contemporânea e a dimensão imagética de obras textuais etc. A maioria parte dos textos provém de uma ocasião específica, o seminário internacional "A letra, a imagem, o livro, o museu: a literatura e as artes depois da virada icônica”, realizado em 7 e 8 de março de 2018 no Instituto de Estudos da Linguagem da Unicamp. Participaram - e têm seus artigos aqui publicados - os professores Raul Antelo, Davi Pessoa, Márcio Seligmann-Silva, Eduardo Jorge de Oliveira, Mario Cámara, Eduardo Sterzi, Tiago Guilherme Pinheiro, Pauline Medea Bachman, Osvaldo Manuel Silvestre, Júlia Studart, Veronica Stigger e Manoel Ricardo de Lima. Também foram integrados ao dossiê textos selecionados a partir da convocação feita pela Remate de Males: é o caso dos artigos de Larissa Averbug e Luiza Novaes e de Andréa Catrópa Silva.

O seminário foi promovido pelo Programa de Pós-Graduação em Teoria e História Literária como evento inaugural de um projeto de colaboração internacional de longo prazo que envolve programas com sede em universidades estrangeiras, como o Programa de Doutoramento em Materialidades da Literatura, da Universidade de Coimbra (Portugal), o Romanisches Seminar, da Universität Zürich (Suíça), e a Maestría en Literaturas de América Latina, da Universidade Nacional de San Martín (Argentina). Ao final de 2018, esse projeto de colaboração internacional, sob o nome geral de Metamorfoses da literatura no tempo das imagens, 
foi contemplado, junto com outros projetos da Unicamp, com o apoio do Programa Institucional de Internacionalização da Capes (Print-Capes).

Eduardo Sterzi (Unicamp)

Eduardo Jorge de Oliveira (Universität Zürich)

Veronica Stigger (FAAP) 